\title{
Kinerja Belanja Daerah Dinas Penanaman Modal Dan Pelayanan Terpadu Satu Pintu Kota Bandung
}

\author{
${ }^{1}$ Cecep Wahyu Hoerudin, ${ }^{2}$ Bayu Eka Lesmana, ${ }^{3}$ Wilda Fatimah \\ ${ }^{1}$ Administrasi Publik, Fakultas Ilmu Sosial dan Ilmu Politik UIN Sunan Gunung Djati Bandung; \\ cecepwahyu@uinsgd.ac.id \\ ${ }^{2}$ Sekolah Tinggi Ilmu Administrasi Cimahi; bayuekalesmana@gmail.com \\ ${ }^{3}$ Administrasi Publik, Fakultas Ilmu Sosial dan Ilmu Politik UIN Sunan Gunung Djati Bandung; \\ fatimahwilda.wf@gmail.com
}

\begin{abstract}
This research was conducted to analyze the performance of spending at the Office of Investment and One Stop Integrated Services (DPMPTSP) of Bandung City in 2013-2017. The analysis of expenditure performance carried out in the study includes: analysis of shopping variance, shopping harmony, expenditure growth and expenditure efficiency ratios that can be a measurement tool in budget realization effectively, efficiently and economically. This research is in the form of descriptive qualitative. The data used is the budget realization report and the results of interviews conducted by researchers. Based on the results of the study, showed that (1) there was a saving in spending and categorized as quite good shopping performance, (2) expenditure growth in 2013-2017 could be said being quite volatile. Expenditure growth in 2013-2016 experienced positive growth while in 2017 experienced negative growth of $-13.09 \%$ due to inflation, (3) the harmony of spending in 2013-2017 can be said to be the absence of budget harmonization in expenditure, (4) the ratio of expenditure efficiency in 2013-2017 already efficient enough, this is proven by the efficiency ratio of less than $100 \%$.
\end{abstract}

Keywords: Spending Performance, Spending Variance Analysis, Spending Growth Analysis, Spending Match Analysis, and Spending Efficiency Ratio.

\section{Pendahuluan}

Pemerintah daerah mempunyai kewajiban untuk mengelola dan mengatur jalannya pemerintahan di lingkup daerah, membangun daerah, serta memberi pelayanan yang baik kepada masyarakat. Untuk dapat mewujudkan pemerintahan yang baik, maka pemerintah harus melakukan upaya peningkatkan akuntabilitas dan keterbukaan dalam pengelolaan keuangan daerah yang disajikan dalam bentuk laporan keuangan. Pengelolaan keuangan di daerah haruslah dikelola secara tertib, sesuai dengan undang-undang yang berlaku, efektif dan efisien, ekonomis, terbuka, dan dapat dipertanggungjawabkan kepada publik dengan berlandaskan kepada asas keadilan, kepatuhan, dan kebermanfaatannya bagi masyarakat luas.

Menurut Elmi (2002) penganggaran merupakan sebuah proses penyusunan perencanaan dana finansial, berupa pendapatan dan pembiayaan, kemudian mendistribusikan dana finansial tersebut untuk setiap program dan kegiatan yang menunjang tercapainya fungsi dan sasaran yang telah digariskan. Lynch (dalam Rubenstein, 2002) memandang penganggaran untuk sektor publik sebagai sebuah perencanaan untuk memperkenalkan setiap program yang berkaitan dengan sasaran dan tujuan dalam suatu periode tertentu, termasuk jumlah estimasi sumber daya yang dibutuhkan, yang biasanya dibandingkan dengan periode lalu dalam rangka untuk memprediksikan kebutuhan apa saja pada saat mendatang. Dalam 
rangka usaha pemberdayaan pemerintahan daerah, Mardiasmo (2002) milihat bahwa pengelolaan keuangan daerah dan anggaran daerah perlu dilakukan beberapa perubahan cara pandang yang lebih sesuai dengan situasi dan dan keadaan saat ini, yaitu sebagai berikut:

1. Pengelolaan keungan perlu berorientasi pada sebesar-besarnya kepentingan masyarakat.

2. Misi pengelolaan keuangan daerah yang jelas dan terang serta keaktifan dan inisiatif pihak-pihak yang memiliki kewenangan dan kekuasaan seperti Kepala Daerah, DPRD, Sekda dan perangkat lainnya dalam pengelolaan anggaran.

3. Profesionalitas pengadaan dan manajemen barang milik daerah.

4. Terdapat beberapa ketentuan dan standar mengenai bentuk dan struktur anggaran kinerja dan anggaran tahunan.

5. Nilai-nilai akuntabilitas sebagai bentuk pengawasan pada laporan keuangan daerah, peran pengawasan anggota Dewan, penyampaian pendapat, kritikan, masukan, dan penilaian kinerja anggaran serta keterbukaan informasi terkait dengan sistem anggaran untuk masyarakat secara umum.

6. Adanya sistem pembinaan dan pengawasan yang profesional, berasal dari peran organisasi masyarakat, lembaga swadaya masyarakat, kelompok asosiasi dan peran anggota masyarakat pada umumnya dalam rangka peningkatan kinerja aparat pemerintah daerah

7. Pengadaam sistem informasi keuangan daerah yang kredibel sebagai media penyediaan informasi terkait penganggaran yang dapat dipertanggung jawabkan

Menganalisis kinerja keuangan pada pemerintah daerah dapat dilakukan dengan cara menganalisis rasio keuangan Anggaran Pendapatan dan Belanja Daerah (APBD) yang telah disepakati berdasarkan berbagai rasio keuangan, di antaranya Rasio Kemandirian Keuangan Daerah, Rasio keserasian, Rasio pertumbuhan serta Rasio Efektivitas dan Efisiensi (Halim, 2012:230). Analisis belanja daerah merupakan analisis yang dilakukan dengan tujuan mengevaluasi APBD, yaitu apakah APBD tersebut telah dikelola secara akuntabel, efektif, efisien, dan transparan oleh pemerintah (Mahmudi, 2016:154). Dapat disimpulkan apabila kinerja anggaran belanja daerah ingin dikatakan baik maka realisasi belanjanya harus lebih rendah dari anggaran dengan adanya efisiensi, bukan karena tidak terserapnya anggaran yang disebabkan oleh adanya beberapa program kerja atau kegiatan yang sudah ada anggarannya namun tidak dilaksanakan. (Mahmudi, 2016:234)

Berdasarkan Laporan Realisasi Anggaran, maka didapatkan informasi yang dapat digunakan dalam membuat analisis kinerja beanja, yang terdiri dari:

\section{Analisis Varians Belanja}

Varians belanja ini terbagi menjadi 2 yaitu: (1) Selisih disukai (favourablevariance) yaitu jika terjadi surplus (realisasi belanja lebih kecil dari anggarannya) (2) Selisih tidak disukai (unfavourable variance) yaitu jika terjadi defisit (realisasi belanja lebih besar dari anggarannya). 
Varians Belania: Realisasi Belanja - Anggaran

2.Analisis Pertumbuhan Belanja

$$
=\frac{\text { Realisasi Belanja Thn } \mathrm{t}-\text { Realisasi Belanja Thn } \mathrm{t} 1}{\text { Realisasi Belanja Thn } \mathrm{t} 1}
$$

\section{Analisis Keserasian Belanja}

a. Analisis belanja operasi terhadap total belanja

$$
=\frac{\text { Realisasi Belanja Operasi }}{\text { Total Belanja Daerah }}
$$

b. Analisis belanja modal terhadap total belanja

$$
=\frac{\text { Realisasi Belanja Modal }}{\text { Total Belanja Daerah }}
$$

c. Analisis belanja langsung dan tidak langsung

1) Analisis belanja langsung terhadap total belanja

$$
=\frac{\text { Total Belanja Langsung }}{\text { Total Belanja Daerah }}
$$

2) Analisis belanja tidak langsung terhadap total belanja

$$
=\mathrm{A} \frac{\text { Total Belanja Tidak Langsung }}{\text { Total Belanja Daerah }}
$$

4.Rasio Efisiensi Belanja

$$
\text { Rasio Efisiensi Belanja }=\frac{\text { Realisasi Belanja }}{\text { Anggaran Belanja }} \times 100 \%
$$

\section{Rasio Belanja terhadap PDRB}

Laporan Realisasi Anggaran (LRA) merupakan alat ukur finansial yang dapat menggambarkan capaian kinerja di pemerintah khususnya pemerintah daerah. Penilaian kinerja berdasarkan Laporan Realisasi Anggaran (LRA) ini dapat diukur dari belanja daerah. Belanja merupakan semua pengeluaran dari rekening kas umum yang dapat mengurangi saldo anggaran lebih dalam periode keuangan yang terkait dan pembayarannya tidak akan dapat diperoleh kembali di masa yang akan datang.

Dengan adanya LRA maka pembaca laporan dapat menganalisis kinerja keuangan pemerintah baik berupa analisis pendapatan, belanja, ataupun pembiayaan. Objek pada penelitian ini adalah kinerja belanja pada Dinas Penanaman Modal dan Pelayanan Terpadu Satu Pintu (DPMPTSP) Kota Bandung. Dinas PMPTSP dipilih menjadi objek penelitian karena DPMPTSP merupakan badan atau instansi yang mengolah dan mengatur keuangan daerah baik itu berupa pendapatan maupun belanja.

Jika dilihat dari laporan realisasi anggaran DPMPTSP Kota Bandung tahun 20132017, realisasi belanja belum mencapai persentase 95\% yang disebabkan masih adanya permasalahan dari segi belanja, seperti adanya kenaikan dan penurunan yang tidak, adanya sisa anggaran yang tidak terealisasikan, realisasi belanja yang belum mencapai target dan 
adanya ketidakseimbangan antara belanja langsung dan tidak langsung. Dengan demikian, berdasarkan pada permasalahan lapangan diatas, penelitian ini memiliki maksud yaitu untuk menganalisis kinerja belanja di Dinas Penanaman Modal dan Pelayanan Terpadu Satu Pintu (DPMPTSP) Kota Bandung tahun 2013-2017.

\section{Metode Penelitian}

Pendekatan kualitatif dengan jenis penelitian deskriptif dijadikan sebagai metode dalam melakukan penelitian ini. Metode ini dilakukan untuk melakukan analisis pada kinerja belanja di Dinas Penanaman Modal dan Pelayanan Terpadu Satu Pintu Kota Bandung tahun 2013-2017. Sumber data yang digunakan merupakan sumber data primer yang berasal dari Laporan Realisasi Anggaran (LRA) yang bersumber dari DPMPTSP Kota Bandung. Dalam rangka mengumpulkan data penelitian, peneliti menggunakan teknik wawancara secara mendalam kepada sejumlah informan yang berada di DPMPTSP Kota Bandung. Selain itu, proses pengumpulan data juga dilakukan dengan observasi dan studi dokumen. Sedangkan untuk melakukan analisis data, penulis menggunakan teknik analisis Miles dan Huberman (2007). Teknik tersebut terdiri dari melakukan pereduksian data, penyajian data dan penarikan kesimpulan.

\section{Hasil Dan Pembahasan}

1. Kinerja Belanja Berdasarkan Analisis Varians

Hasil varians belanja pada DPMPTSP Kota Bandung menunjukkan bahwa telah melakukan penghematan anggaran secara baik, yang ditunjukan dalam tabel berikut:

Tabel 3. 1

Analisis Varians Belanja

\begin{tabular}{ccccc}
\hline Tahun & $\begin{array}{c}\text { Anggaran } \\
(\mathbf{R p})\end{array}$ & $\begin{array}{c}\text { Realisasi } \\
(\mathbf{R p})\end{array}$ & $\begin{array}{c}\text { Varians } \\
\text { (Selisih) }\end{array}$ & $\begin{array}{c}\text { Persentase } \\
(\boldsymbol{\%})\end{array}$ \\
\hline $\mathbf{2 0 1 3}$ & 21.513 .370 .034 & 19.009 .511 .162 & $(2.503 .858 .872)$ & $(11,63) \%$ \\
$\mathbf{2 0 1 4}$ & 31.234 .348 .573 & 20.548 .471 .709 & $(10.685 .876 .864)$ & $(34,21) \%$ \\
$\mathbf{2 0 1 5}$ & 36.794 .064 .407 & 31.233 .184 .621 & $(5.560 .879 .786)$ & $(15,11) \%$ \\
$\mathbf{2 0 1 6}$ & 35.832 .662 .292 & 32.667 .112 .569 & $(3.165 .549 .723)$ & $(8,83) \%$ \\
$\mathbf{2 0 1 7}$ & 35.431 .846 .728 & 28.389 .334 .186 & $(7.042 .512 .542)$ & $(19,87) \%$ \\
\hline
\end{tabular}

Sumber: Diolah Oleh Peneliti, 2018

Pada tahun 2013 varians belanja sebesar 11,63\% dengan daya serap anggaran sebesar 88,36\%, naik pada tahun 2014 menjadi 34,21\%, daya serap anggaran sebesar 65,79\% yang menunjukkan angka rendah yang disebabkan adanya program sarana dan prasarana aparatur yang tidak terlaksana. Pada tahun 2015 varians belanja turun menjadi 15,11\% dengan daya serap anggaran sebesar 84,89\% dalam CaLK tahun 2015 dijelaskan salah satu penyebab masih adanya selisih yaitu adanya pergantian pejabat pada saat kegiatan dan anggaran yang sedang berjalan sedangkan tahun 2016 persentase varians turun menjadi 8,83\%, daya serap anggaran sebesar 91,72\% dan pada tahun 2017 persentase varians naik kembali menjadi $19,87 \%$ dengan daya serap anggaran sebesar $80,12 \%$. Dengan demikian kinerja belanja berdasarkan analisis varians belanja dapat dikategorikan baik (favourable variance) karena penggunaan realisasi tidak melebihi anggaran. 
2. Kinerja Belanja Berdasarkan Analisis Pertumbuhan

Pertumbuhan belanja digunakan untuk mengetahui perkembangan pertumbuhan tiap tahunnya dan mengetahui komponen mana yang perlu diperhatikan setelah evaluasi pada kinerja belanja.

Tabel 3.2

Analisis Pertumbuhan Belanja

\begin{tabular}{cccc}
\hline Tahun & $\begin{array}{c}\text { Realisasi } \\
\text { Belanja }\end{array}$ & $\begin{array}{c}\text { Pertumbuhan } \\
\text { Belanja }\end{array}$ & $\begin{array}{c}\text { Persentase } \\
(\mathbf{\%})\end{array}$ \\
\hline $\mathbf{2 0 1 3}$ & 19.009 .511 .162 & - & - \\
$\mathbf{2 0 1 4}$ & 20.548 .471 .709 & 1.538 .960 .547 & $8,09 \%$ \\
$\mathbf{2 0 1 5}$ & 31.233 .184 .621 & 10.684 .692 .912 & $51,99 \%$ \\
$\mathbf{2 0 1 6}$ & 32.667 .112 .569 & 1.433 .947 .948 & $4,59 \%$ \\
$\mathbf{2 0 1 7}$ & 28.389 .334 .186 & $(4.277 .778 .383)$ & $(13,09 \%)$ \\
\hline \multicolumn{4}{c}{ Sumber: Diolah Oleh Peneliti, 2018 }
\end{tabular}

Pertumbuhan belanja di DPMPTSP Kota Bandung tahun 2013-2017 dapat dikatakan cukup fluktuatif mengalami kenaikan yang berarti positif dan penurunan yang berarti negatif. Pertumbuhan belanja tahun 2013 ke 2014 sebesar 10,75\% meningkat pesat tahun 2014 ke 2015 menjadi 51,99\% yang disebabkan oleh terjadinya inflasi yang tinggi pada tahun tersebut dan turun pada tahun 2016 ke 2017 mengalami persentase pertumbuhan yang negatif sebesar $-13,09 \%$ yang disebabkan oleh tingkat inflasi, penggunaan anggaran pada belanja langsung dan realisasi anggaran yang lebih besar dibanding periode akuntansi atau tahun sebelumnya.

Tabel 3.3

Inflasi Kota Bandung tahun 2013-2017

\begin{tabular}{cc}
\hline Tahun & Tingkat Inflasi (\%) \\
\hline $\mathbf{2 0 1 3}$ & $7,97 \%$ \\
$\mathbf{2 0 1 4}$ & $7,76 \%$ \\
$\mathbf{2 0 1 5}$ & $3,93 \%$ \\
$\mathbf{2 0 1 6}$ & $2,93 \%$ \\
$\mathbf{2 0 1 7}$ & $3,46 \%$ \\
\hline \multicolumn{2}{l}{ Sumber:www.bandungkota.bps.go.id, 2018 }
\end{tabular}

3. Kinerja Belanja Berdasarkan Keserasian Belanja

Kinerja belanja berdasarkan analisis keserasian belanja menunjukkan bahwa DPMPTSP Kota Bandung tahun 2013-2017 belum melaksanakan harmonisasi dalambelanja, yang dapat dilihat dari proporsi belanja langsung lebih kecil daripada belanja tidak langsung pada tahun 2013, 2014 dan 2017. Berbeda dengan porsi realisasi anggaran belanja yang dialokasikan untuk belanja operasional cukup tinggi mencapai rata-rata sebesar 90,51\% dapat dikatakan wajar dan serasi karena belanja operasi lebih mendominasi terhadap belanja daerah masih dalam persentase 60-90\%. Sedangkan untuk belanja modal, porsi realisasi anggarannya masih dikatakan wajar dalam persentase 5-20\% terkecuali pada tahun 2017 dengan persentase sebesar $4,49 \%$. 


\section{a. Analisis Belanja Operasi Terhadap Total Belanja}

Hasil analisis pada belanja operasi terhadap total belanja dikatakan cukup fluktuatif. Tahun 2013 persentase belanja operasi sebesar 93,64\%, dari total belanja. Kemudian Tahun 2014-2015 terjadi penurunan dan kembali meningkat di tahun 2017, kenaikan ini terjadi karena pada tahun 2017 belanja pegawai yang mendominasi penggunaan belanja operasi sebesar Rp.18.973.187.435.

Dapat dijelaskan bahwa porsi realisasi anggaran belanja yang dialokasikan untuk belanja operasional cukup tinggi mencapai rata-rata sebesar 90,51\% dibandingkan dengan alokasi yang dianggarkan dalam belanja modal.

Tabel 3.4

Analisis Belanja Operasi terhadap Total Belanja

\begin{tabular}{cccc}
\hline Tahun & $\begin{array}{c}\text { Realisasi } \\
\text { Belanja Operasi } \\
(\mathbf{R p})\end{array}$ & $\begin{array}{c}\text { Total Belanja } \\
\text { Daerah }(\mathbf{R p})\end{array}$ & $\begin{array}{c}\text { Rasio Belanja } \\
\text { Operasi terhadap } \\
\text { Total Belanja (\%) }\end{array}$ \\
\hline $\mathbf{2 0 1 3}$ & 17.801 .816 .412 & 19.009 .511 .162 & $93,64 \%$ \\
$\mathbf{2 0 1 4}$ & 18.884 .111 .259 & 20.548 .471 .709 & $91,90 \%$ \\
$\mathbf{2 0 1 5}$ & 27.489 .869 .261 & 31.233 .164 .621 & $88,01 \%$ \\
$\mathbf{2 0 1 6}$ & 27.273 .327 .704 & 32.667 .112 .569 & $83,48 \%$ \\
$\mathbf{2 0 1 7}$ & 27.112 .403 .786 & 28.389 .334 .186 & $95,50 \%$ \\
\hline
\end{tabular}

Sumber: Diolah Oleh Peneliti, 2018

b. Analisis Belanja Modal Terhadap Total Belanja

Berdasarkan pada hasil analisis yang dilakukan pada belanja modal terhadap total belanja terdapat kenaikan dari tahun 2013-2016 sedangkan tahun 2017 terjadi penurunan yang cukup signifikan yaitu 4,49\%. Adanya penurunan dari tahun 2016 ke 2017 dikarenakan belanja jalan, irigasi dan jaringan yang telah dilakukan pada tahun 2016. Pada tahun 2017 hanya menggunakan belanja sebesar Rp.1.276.930.400.

Tabel 3.5

Analisis Belanja Modal Terhadap Total Belanja

\begin{tabular}{cccc}
\hline Tahun & $\begin{array}{c}\text { Realisasi Belanja } \\
\text { Modal (Rp) }\end{array}$ & $\begin{array}{c}\text { Total Belanja } \\
\text { Daerah (Rp) }\end{array}$ & $\begin{array}{c}\text { Rasio Belanja } \\
\text { Modal terhadap } \\
\text { Total Belanja (\%) }\end{array}$ \\
\hline $\mathbf{2 0 1 3}$ & 1.207 .694 .750 & 19.009 .511 .162 & $6,35 \%$ \\
$\mathbf{2 0 1 4}$ & 1.664 .360 .450 & 20.548 .471 .709 & $8,09 \%$ \\
$\mathbf{2 0 1 5}$ & 3.743 .315 .360 & 31.233 .164 .621 & $11,98 \%$ \\
$\mathbf{2 0 1 6}$ & 5.593 .784 .865 & 32.667 .112 .569 & $17,12 \%$ \\
$\mathbf{2 0 1 7}$ & 1.276 .930 .400 & 28.389 .334 .186 & $4,49 \%$ \\
\hline \multicolumn{4}{c}{ Sumber: Diolah Oleh Peneliti, 2018 }
\end{tabular}

c. Analisis Belanja Langsung Dan Tidak Langsung

Perhitungan pada tabel belanja langsung dan belanja tidak langsung tahun 2013 menunjukkan realisasi dari anggaran belanja langsung mencapai $42,60 \%$ sedangkan belanja tidak langsung sebesar 57,31\%. Dari tahun 2013-2015 realisasi belanja langsung ini terus naik dam pada Tahun 2014 rasio belanja mencapai 45,35\% dan meningkat kembali di tahun 
2015 menjadi 57,03\%. Namun pada tahun 2016 dan 2017 menurun. Untuk belanja tidak langsung menurun dari tahun 2013-2015 dan naik kembali pada tahun 2016 dan 2017.

Tabel 3.6

Analisis Belanja Langsung Terhadap Total Belanja

\begin{tabular}{cccc}
\hline Tahun & $\begin{array}{c}\text { Realisasi } \\
\text { Belanja } \\
\text { Langsung (Rp) }\end{array}$ & $\begin{array}{c}\text { Total Belanja } \\
\text { Daerah (Rp) }\end{array}$ & $\begin{array}{c}\text { Rasio Belanja } \\
\text { Langsung terhadap } \\
\text { Total Belanja (\%) }\end{array}$ \\
\hline $\mathbf{2 0 1 3}$ & 8.099 .612 .562 & 19.009 .511 .162 & $42,60 \%$ \\
$\mathbf{2 0 1 4}$ & 9.319 .075 .848 & 20.548 .471 .709 & $45,35 \%$ \\
$\mathbf{2 0 1 5}$ & 17.812 .642 .808 & 31.233 .164 .621 & $57,03 \%$ \\
$\mathbf{2 0 1 6}$ & 16.938 .177 .987 & 32.667 .112 .569 & $51,85 \%$ \\
$\mathbf{2 0 1 7}$ & 9.416 .146 .751 & 28.389 .334 .186 & $33,16 \%$ \\
\hline
\end{tabular}

Sumber: Diolah Oleh Peneliti, 2018

Tabel 3.7

Analisis Belanja Tidak Langsung Terhadap Total Belanja

\begin{tabular}{cccc}
\hline Tahun & $\begin{array}{c}\text { Realisasi } \\
\text { Belanja Tidak } \\
\text { Langsung (Rp) }\end{array}$ & $\begin{array}{c}\text { Total Belanja } \\
\text { Daerah }(\mathbf{R p})\end{array}$ & $\begin{array}{c}\text { Rasio Belanja Tidak } \\
\text { Langsung terhadap } \\
\text { Total Belanja (\%) }\end{array}$ \\
\hline $\mathbf{2 0 1 3}$ & 10.909 .898 .600 & 19.009 .511 .162 & $57,31 \%$ \\
$\mathbf{2 0 1 4}$ & 11.229 .395 .861 & 20.548 .471 .709 & $54,64 \%$ \\
$\mathbf{2 0 1 5}$ & 13420.541 .813 & 31.233 .164 .621 & $42,96 \%$ \\
$\mathbf{2 0 1 6}$ & 15.926 .934 .592 & 32.667 .112 .569 & $48,75 \%$ \\
$\mathbf{2 0 1 7}$ & 18.973 .187 .435 & 28.389 .334 .186 & $66,83 \%$ \\
\hline
\end{tabular}

Sumber: Diolah Oleh Peneliti, 2018

4. Kinerja Belanja Berdasarkan Rasio Efisiensi Belanja

Kinerja belanja berdasarkan rasio efisiensi belanja, DPMPTSP tahun 2013-2017 telah melakukan efisiensi yang baik, yang dapat dilihat dari tingkat rasio efisiensi yang tidak mencapai 100\%. Namun realisasi belanja belum mencapai 95\%. Pada tahun 2013 sebesar $88,36 \%$ turun pada tahun 2014 menjadi $65,79 \%$ selanjutnya naik tahun 2015 sebesar 84,89\% dan tahun 2016 sebesar 91,72\%. Namun turun kembali pada tahun 2017 menjadi 80,12\%. Penurunan pada tahun 2014 dan 2017 terjadi karena adanya kegiatan dan program yang belum dilakukan pada tahun tersebut. Secara keseluruhan rata-rata efisiensi belanja yaitu sebesar $82,05 \%$ dan dikategorikan cukup efisien.

Tabel 3.8

Rasio Efisiensi Belanja

\begin{tabular}{cccc}
\hline Tahun & $\begin{array}{c}\text { Anggaran Belanja } \\
(\mathbf{R p})\end{array}$ & $\begin{array}{c}\text { Realisasi Belanja } \\
(\mathbf{R p})\end{array}$ & $\begin{array}{c}\text { Rasio Efisiensi } \\
\text { Belanja\% }\end{array}$ \\
\hline $\mathbf{2 0 1 3}$ & 21.513 .270 .034 & 19.009 .511 .162 & $88,36 \%$ \\
$\mathbf{2 0 1 4}$ & 31.234 .348 .573 & 20.548 .471 .709 & $65,79 \%$ \\
$\mathbf{2 0 1 5}$ & 36.794 .064 .407 & 31.233 .184 .621 & $84,89 \%$ \\
$\mathbf{2 0 1 6}$ & 35.832 .662 .292 & 32.667 .112 .569 & $91,72 \%$ \\
$\mathbf{2 0 1 7}$ & 35.431 .846 .728 & 28.389 .334 .186 & $80,12 \%$ \\
\hline \multicolumn{4}{c}{ Sumber: Diolah Oleh Peneliti, 2018 }
\end{tabular}




\section{Simpulan}

Hasil varians belanja Dinas Penanaman Modal dan Pelayanan Terpadu Satu Pintu (DPMPTSP) Kota Bandung tahun 2013-2017 telah menunjukan kinerja yang baik, sesuai dengan teori Mahmudi yang menyatakan bahwa kinerja anggaran disebut baik apabila realisasinya tidak melebihi anggaran. Untuk hasil pertumbuhan belanja DPMPTSP Kota Bandung tahun 2013-2017 dapat dikatakan cukup fluktuatif, pada tahun 2013-2016 mengalami kenaikan dan penurunan tetapi bergerak positif berbeda dengan tahun 2017 yang mempunyai persentase negatif yang disebabkan oleh terjadinya inflasi dan tidak terlaksananya suatu program yang sudah dianggarkan. Hasil analisis keserasian belanja menunjukkan bahwa DPMPTSP Kota Bandung belum melakukan harmonisasi belanja, dilihat dari belanja langsung yang lebih kecil daripada belanja tidak langsung pada tahun 2013, 2014 dan 2017. Sedangkan untuk belanja operasi dan belanja modal sudah serasi dapat dilihat dari belanja modal yang lebih kecil daripada belanja operasi dilihat dari porsinya. Hasil rasio efisiensi belanja menunjukkan bahwa DPMPTSP Kota Bandung sudah melakukan efisiensi dengan baik karena tingkat rasio efisiensi tidak melebihi $100 \%$. Sedangkan secara keseluruhan rata-rat efisiensi belanja yaitu sebesar $82,05 \%$ yang termasuk dalam kategori cukup efisien. Namun jika dilihat dari daya serap anggaran cukup rendah.

\section{Referensi}

Darman, D. (2016). Pengaruh Pajak Daerah Dan Dana Alokasi Umum Terhadap Sisa Lebih Pembiayaan Anggaran (Survey Pada Kabupaten/Kota Di Provinsi Sulawesi Tengah). e Jurnal Katalogis, Volume 4 Nomor 6, ISSN: 2302-2019.

Halim, A. (2012). Akuntansi Sektor Publik :Akuntansi Keuangan daerah. Jakarta: Salemba Empat.

Halim, A. (2016). Manajemen Keuangan Sektor Publik Problematika Penerimaan dan Pengeluaran Pemerintah. Jakarta: Salemba Empat.

Iregar, B. (2015). Akuntansi Sektor Publik (Akuntansi Keuangan Daerah Berbasis Akrual). Yogyakarta: UPP STIM YKPN.

Izudin, H., Syaparudin., dan M. Syamsudin. H. (2013). Kinerja Keuangan Daerah Dan Hubungan Dengan Silpa Di Kabupaten Bungo. Jurnal Perspektif Pembiayaan dan Pembangunan Daerah. Vol. 1 No.1.

Juanda. (2008). Hukum Pemerintah Daerah. Bandung: Alumni.

Mahmudi. (2016). Analisis Laporan Keuangan Pemerintah Daerah. Yogyakarta: UPP AMP YKPN.

Mahsun, M. (2016). Pengukuran Kinerja Sektor Publik. Yogyakarta: BPFE Yogyakarta .

Mursyidi. (2009). Akuntansi Pemerintahan di Indonesia. Bandung :PT Refika Aditama

Pasolong, H. (2013). Teori Administrasi Publik. Bandung : Alfabeta.

Saidi, M.D. (2010). Manajemen Keuangan Pemerintahan. Yogyakarta: Graha Ilmu.

Silalahi, U. (2012). Metode Penelitian Sosial. Bandung : RefikaAditama.

Suwanda, D. (2015). Sistem Akuntansi Akrual Pemerintah Daerah Berpedoman SAP Berbasis Akrual. Jakarta:Penerbit PPM. 